\section{Acknowledgments}

I am grateful to Mr Guy Baines for his help and encouragement and for his permission to publish these two cases; also to Mr T. F. Dee for the photographs. My thanks to Miss V. J. Barlow for her secretarial help.

\section{References}

Kille, J.N. \& Glick, S. (1967) Neoplasia complicating ureterosigmoidostomy. British Medical Journal, 4, 783.

Kozak, J.A., Watkins, W.E. \& Jewell, W.R. (1966) Neoplastic stomal obstruction: A complication of ureterosigmoidostomy. Journal of Urology, 96, 691 .

MACGregor, A.M.C. (1968) Muscus-secreting adenomatous polyp at the site of ureterosigmoidostomy: A case report and review of the literature. British Journal of Surgery, 55, 591.

Markowitz, A.M. \& Koontz, P. (1966) The development of colonic polyps at the site of ureteral implantation. Surgery, 60, 761 .
Marshall, S., Lyon, R.P. \& Minkler, D. (1966) Ureteral dilatation following use of oral contraceptives. Journal of the American Medical Association, 198, 782.

Oetjen, L.H., Campbell, J.L., Thomley, M.W. \& Parsons, R.L. (1970) Carcinoma of the colon following ureterosigmoidostomy. Journal of Urology, 104, 536.

RichteR, R.M. \& Ginsberg, S.A. (1967) Late development of colonic carcinoma complicating ureterosigmoidostomy. American Journal of Surgery, 113, 843.

ScotT, W.W. \& Boyd, H.L. (1953) Study of carcinogenic effect of betanaphthylamine on normal and substituted isolated sigmoid loop bladder of dogs. Journal of Urology, $70,914$.

Sommo, G. \& Traverso, G.B. (1968) Histochemical changes in the rectal mucosa after ureterosigmoidostomy. Pathologica, 59, 447.

Urdaneta, L.F., Duffell, D., Creevy, C.D. \& Aust, J.B. (1966) Late development of primary carcinoma of the colon following ureterosigmoidostomy: Report of three cases and literature review. Annals of Surgery, 164, 503.

Whittaker, R.H., Pugh, R.C.B.\& Dow, D. (1971) Colonic tumours following ureterosigmoidostomy. British Journal of Urology, 43, 562.

\title{
A neonatal complication of maternal leukaemia treated with 6-mercaptopurine
}

\author{
J. B. MCCONNELL \\ M.B., D.C.H.
}

\author{
R. BHOOLA \\ M.B.
}

\section{Department of Medicine, King Edward VIII Hospital, Durban, S. Africa}

\begin{abstract}
Summary
A 24-year-old African mother, who had received 6-mercaptopurine for acute leukaemia from before conception and throughout her pregnancy is described. The child, born prematurely, was anaemic at birth, with many features of a micro-angiopathic haemolytic anaemia. It is suggested that the mother's disease or treatment was involved in the aetiology of this anaemia.
\end{abstract}

\section{Introduction}

Acute leukaemia is uncommon in females of child-bearing age. Most cases associated with pregnancy are diagnosed during the pregnancy, usually after the first trimester (Hoover \& Schumacher, 1966). We can find reports of only four patients who had been receiving cytotoxic drugs at the time of conception (Merskey \& Rigal, 1956; Parekh, Shah \& Sharma, 1959; Rothberg, Conrad \&

Correspondence: J. B. McConnell, Royal Belfast Hospital for Sick Children, Belfast.
Cowley, 1959; Frenkel and Meyers, 1960). In only two (Parekh et al., 1959; Frenkel \& Meyers, 1960) was the drug continued for the duration of the pregnancy.

We report the case of an infant of a mother who received 6-mercaptopurine from before conception until delivery. The child had an abnormal blood picture from birth. This feature has not been reported before in an infant of a leukaemic mother.

\section{Case history}

A 24-year-old African primigravida presented in November 1969 with excessive bleeding after tooth extraction. A peripheral blood examination revealed a picture of myeloblastic leukaemia, which was confirmed by marrow biopsy. Treatment was started with 6-mercaptopurine in a dose of $50 \mathrm{mg}$ twice daily.

A remission was induced and lasted until June 1970, when the patient was transferred to our care. She felt well and physical examination revealed no 
abnormality. However, the white cell count was $4000 / \mathrm{mm}^{3}$ with $5 \%$ blast cells, and so 6 -mercaptopurine was continued. The blood picture deteriorated, so that 3 months later there were $96 \%$ blast cells and she was markedly anaemic. At this time she was found to be pregnant. History and examination indicated that conception had occurred in early June.

Marrow biopsy showed acute myeloblastic leukaemia and prednisone was added. There was no response to this combined therapy, but the patient felt well and the pregnancy progressed normally. On 5 January, at approximately 32 weeks gestation, she delivered a live premature male infant of $1.81 \mathrm{~kg}$. Delivery was covered with platelet-rich blood because of severe thrombocytopenia but there was no excessive bleeding.

Post-partum the patient developed an E. coli septicaemia and despite antibiotics she died on the sixteenth day post-delivery, after an episode of intestinal haemorrhage.

Necropsy revealed generalized peritonitis due to an ileal perforation. There was evidence of leukaemic infiltration of spleen and lymph glands, including mesenteric glands, but no infiltration was seen around the perforation in the ileum. There was also evidence of generalized septicaemia.

The baby had no physical malformations, but was anaemic at birth $(\mathrm{Hb} 10.2 \mathrm{~g} / 100 \mathrm{ml})$, with a blood picture showing many of the morphological characteristics of a micro-angiopathic haemolytic anaemia. There were microspherocytes, schistocytes, crenated and fragmented cells. The platelets, however, were always normal in number. The spleen was palpable. The peripheral blood film showed $2 \%$ blast cells which disappeared within 10 days. However, fragmented cells remained, and were still present at the age of five months. The reticulocyte count was $12 \%$ at birth and continued to be raised at about $5 \%$ for 4 months. Serum bilirubin levels were not increased and haemolytic studies on two occasions revealed no abnormality. There was no haemoglobinopathy or glucose-6-phosphate dehydrogenase deficiency. The Coombs and Donath-Landsteiner tests were negative, and no antibodies were found in the blood. The blood urea was always normal. No cytomegalic inclusion bodies were found in the child's urine. A bone marrow biopsy showed a normoblastic hypercellular marrow.

The child made steady progress. He was discharged when 5 months old, weighing $4.53 \mathrm{~kg}$. He seemed well, though he was slightly anaemic and still had a palpable spleen. At 9 months he weighed $7 \cdot 24 \mathrm{~kg}$ and had a mild normochromic normocytic anaemia (Hb $10 \mathrm{~g} / 100 \mathrm{ml})$. The reticulocyte count had returned to normal and the spleen was just palpable.

\section{Discussion}

In cases of acute leukaemia associated with pregnancy the outlook for mother and child is poor but has improved over the last two decades (Hoover \& Schumacher, 1966). This has been due to better medical treatment, including the use of blood transfusion and antibiotics. Steroids and cytotoxic drugs have been major improvements in the treatment regimens. The risk of foetal malformations has always been a concern with these drugs and has been considered to be much greater with cytotoxics than steroids. Nicholson (1968) reviewing cytotoxic drugs in pregnancy confirmed that the risks to the foetus were greatest when the drugs were given in the first trimester. 6-mercaptopurine was one of the drugs most used in this period. In twelve pregnancies in which 6-mercaptopurine was given in the first tri-

TABLE 1. Cases in which mother was receiving cytotoxics at conception

\begin{tabular}{|c|c|c|c|c|c|}
\hline Author & Type & $\begin{array}{c}\text { Duration of } \\
\text { treatment }\end{array}$ & Drugs & $\begin{array}{c}\text { Foetal } \\
\text { outcome }\end{array}$ & $\begin{array}{l}\text { Maternal } \\
\text { outcome }\end{array}$ \\
\hline Merskey \& Rigal (1956) & ALL & $\begin{array}{l}\text { Conception } \\
\text { to } \\
7 / 12 \text { gestation }\end{array}$ & $\begin{array}{l}\text { 6. M-P } \\
\quad+ \\
\text { steroids }\end{array}$ & $\begin{array}{c}\text { Premature } \\
\text { died at } \\
2 \text { days }\end{array}$ & $\begin{array}{l}\text { Died } \\
2 / 12 \\
\text { post-partum }\end{array}$ \\
\hline Parekh et al. (1959) & AGL & $\begin{array}{l}\text { Conception } \\
\text { to } \\
\text { delivery }\end{array}$ & $\begin{array}{c}6 \mathrm{M}-\mathrm{P} \\
+ \\
\text { ACTH }\end{array}$ & $\begin{array}{l}\text { Stillborn } \\
\text { at } \\
7 / 12\end{array}$ & $\begin{array}{l}\text { Died } \\
\text { during } \\
\text { delivery }\end{array}$ \\
\hline Rothberg et al. (1959) & AGL & $\begin{array}{l}\text { Conception } \\
\text { to } \\
4 / 12 \text { gestation }\end{array}$ & $\begin{array}{l}6 \text { M-P } \\
+ \\
\text { cortisone } \\
\text { demecolcin } \\
\text { aminopterin }\end{array}$ & $\begin{array}{l}\text { Premature } \\
\text { died at } \\
12 \mathrm{hr}\end{array}$ & $\begin{array}{l}\text { Died } \\
5 \text { days } \\
\text { post-partum }\end{array}$ \\
\hline Frenkel \& Meyers (1960) & Stem cell & $\begin{array}{l}\text { Conception } \\
\text { to } \\
\text { delivery }\end{array}$ & $6 \mathrm{M}-\mathrm{P}$ & $\begin{array}{l}\text { Living } \\
\text { and } \\
\text { well }\end{array}$ & $\begin{array}{l}\text { In remission } \\
\quad \text { at } \\
\text { report }\end{array}$ \\
\hline Present case (1971) & AGL & $\begin{array}{l}7 / 12 \text { prior to } \\
\text { conception } \\
\text { to delivery }\end{array}$ & $\begin{array}{c}6 \mathrm{M}-\mathrm{P} \\
+ \\
\text { steroids }\end{array}$ & Living & $\begin{array}{l}\text { Died } \\
16 \text { days } \\
\text { post-partum }\end{array}$ \\
\hline
\end{tabular}

AGL, acute granulocytic leukaemia; ALL, acute lymphocytic leukaemia. 
mester, there was one malformed foetus reported. However, irradiation and other cytotoxics had also been used in this case.

Animal experiments have shown that one of the most sensitive periods of inducing foetal abnormalities with 6-mercaptopurine is at implantation (Thiersch, 1954). However, in humans it is rare for the mother to be receiving cytotoxic drugs at the time of conception. The present case is only the fifth in the medical literature, in which this has been reported (Table 1). In this small series no foetal abnormalities were reported, but only two of the five survived.

However, the child in the present report did have a blood picture similar in some respects to a microangiopathic haemolytic anaemia. It is the first report we can find of an abnormal blood picture at birth in a child born to a leukaemic mother, besides a report of maternal leukaemic cells being found in the baby's blood as a result of transplacental passage (Rigby, Hanson \& Smith, 1964). This indeed may be the explanation of the blast cells in the infant's blood in the present case.

Both the nature and cause of the child's peripheral blood picture are difficult to explain. The process did not appear to be acute, in that features were still present after 5 months. The blood urea was normal. The usual causes of a haemolytic anaemia were excluded and no evidence was found to suggest an immune basis. The fact that the blood picture was abnormal from birth suggests that the aetiological factors were active during intra-uterine life, and therefore possibly related to the mother's disease or drug therapy.

\section{Acknowledgments}

We wish to thank Dr F. J. Davidson, M.R.C.P., and Dr H. Greig, and the Medical Superintendent of the King Edward VIII Hospital for permission to publish this case report.

\section{References}

Frenkel, E.P. \& MeYers, M.C. (1960) Acute leukaemia and pregnancy. Annals of Internal Medicine, 53, 656.

Hoover, B.A. \& Schumacher, H.R. (1966) Acute leukaemia in pregnancy. American Journal of Obstetrics and Gynecology, 96, 316.

Merskey, C. \& Rigal, W. (1956) Pregnancy in acute leukaemia treated with 6-mercaptopurine. Lancet, ii, 1268.

Nicholson, H.O. (1968) Cytotoxic drugs in pregnancy. Journal of Obstetrics and Gynaecology of the British Commonwealth, 75, 307.

Parekh, J.G., Shah, K.M. \& Sharma, R.S. (1959) Acute leukaemia and pregnancy. Journal of the JJ Group of Hospitals and Grant Medical College, 4, 49.

Rigby, P.G., Hanson, T.A. \& Smith, R.S. (1964) Passage of leukaemic cells across the placenta. New England Journal of Medicine, 271, 124.

Rothberg, H., Conrad, M.E. \& Cowley, R.G. (1959) Acute granulocytic leukaemia in pregnancy. American Journal of the Medical Sciences, 237, 194.

ThIERSCH, J.B. (1954) The effect of 6-mercaptopurine on the rat foetus and on reproduction of the rat. Annals of the New York Academy of Sciences, 60, 220.

\title{
The auriculo-temporal syndrome
}

\author{
S. S. SHAH \\ M.D. \\ A. P. SHaH \\ M.D., D.V. \& D. \\ H. V. DosHI
M.D. \\ N. D. Patel \\ M.B., B.S.

\section{M.P. Shah Medical College and Irwin Group of Hospitals, Jamnagar, Gujarat State, India}

SwEATING on the lips, forehead and nose, after eating hot spicy foods occurs physiologically in many persons. Gustatory sweating-excessive sweating during eating in the distribution of the auriculotemporal nerve, was described by Frey (1923) in a patient following an infected bullet-wound of the parotid gland. Since then his name has been associated with this condition, although the condition was described earlier by Duphenix (1757), and later by Baillarger (1853) and Weber (1897-98). Gustatory sweating has also been reported in areas supplied by other branches of the trigeminal nerve, by the greater auricular nerve, the supraclavicular nerve and the nervus cutaneous colli (Chisa, Mendelson \& Darnley, 1964).

The auriculo-temporal syndrome has been 